https://doi.org/10.31470/2706-7904-2021-16-326-331

\title{
ВИВЧЕННЯ ОСОБЛИВОСТЕЙ ІНТЕРПРЕТАЦЙНОЇ ДІЯЛЬНОСТІ У МОЛОДШОМУ ШКІЛЬНОМУ ВІЦІ
}

\section{The Study of Features of the Interpretation Activity in Primary School Age}

\section{Nataliia Shevchenko}

Dr. Sc. in Psychology, Professor

Zaporizhzhia national university (Ukraine)

shevchenkonf.20@gmail.com

https://orcid.org/0000-0002-5297-6588

\section{Maryna Suriakova}

Ph.D. in Psychology, Associate Professor

Dnipro University of customs and finance (Ukraine)

romas@ua.fm

https://orcid.org/0000-0003-4678-8414

\begin{abstract}
The abstract presents results of an empirical study of the interpretive activity of primary school age children. The authors suggest that human cognitive activity is associated not only with the issue of understanding, but also with the need to interpret what is clear, as well as to develop their own attitude to it. It has been shown that a primary school age child shows the ability to consciously understand any phenomenon and to interpret what he or she understands. The authors have proven the possibility to explore the interpretive activity features in primary school age with the help of interpretive tasks. The research has found that the success of individual interpretive actions determines the quality of interpretive activities in general. Results of the study of the primary school age children interpretive activity have revealed that the greatest difficulties are related to the establishment of subtext, semantic contradiction, semantic connection of contexts, explanation of reasons, and justification of opinion.
\end{abstract}

Key words: interpretation, interpretive activity, interpretation task, primary school age.

\section{Вступ Introduction}

Інтерпретаційна діяльність особистості розглядається в психології як пізнавальна активність, яка визначається іiі інтелектуальними та особистісними особливостями. Особистісний характер інтерпретації проявляється у тому, що вона 
отримується власними зусиллями особистості, $є$ результатом роботи мислення та свідомості (Славська, 2002; Шевченко, 2013). Представники інтерпретуючої лінгвістики трактують інтерпретацію як процес і результат «декодування закодованого», смисл тексту конструюється відповідно до стратегії інтерпретації, текст і окремі лексичні одиниці допускають різні тлумачення (Валуйська, 2012; Акімова, 2012; Уланович, 2001; Гижа, 2005; Ядровська, 2012 та ін.). Реалізація інтерпретаційної діяльності відбувається через відповідні інтерпретаційні дії та операції. Здійснюючи інтерпретаційну діяльність, особистість здатна розвивати інтерпретаційні навички протягом життя та набувати уміння інтерпретувати. Віковий аспект дослідження інтерпретаційної діяльності особистості передбачає вивчення ранніх етапів формування здатності до інтерпретації, що потребує спеціалізованого дослідження.

Дослідницький інтерес до інтерпретаційної діяльності дітей молодшого шкільного віку обумовлений змінами соціального статусу дитини, яка стає школярем, та зі зміною основного виду діяльності. Саме у період навчання у молодшій школі дитина починає активно засвоювати письмову форму мови, взаємодіяти з тестовим навчальним матеріалом. Науковці відмічають у дітей цього віку стрімке засвоєння метафоричної та ідіоматичної лексики рідної мови. У активному слововживанні спостерігається значна кількість фразеологізмів, ярких метафор, образних висловлень. Тому у нашому дослідженні було застосовано саме текстовий матеріал, який підлягав інтерпретуванню молодшими школярами (Барташніков, 1998; Тихомирова, 2002). Емпіричне дослідження проблеми особливостей інтерпретаційної діяльності у молодшому шкільному віці стало основою викладу даного представленого матеріалу.

Мета дослідження полягає у вивченні особливостей розвитку інтерпретаційної діяльності особистості у молодшому шкільному віці та визначення рівня сформованості окремих інтерпретаційних дій через вирішення інтерпретаційних завдань.

\section{Методи та методики дослідження} Methods and Techniques of the Research

Дослідження інтерпретаційних можливостей молодшого школяра відбувалося через постановку відповідних інтерпретаційних завдань: пояснити явище, встановити причинно-наслідковий зв'язок, висунути гіпотезу, розглянути об'єкт з різних точок зору, припустити позицію іншого, виявити значення і смисл, усвідомити власне ставлення, сформулювати висновок у формі думки. У здійсненні цих інтерпретаційних дій виступають пізнавальні операції аналізу, синтезу, 
абстрагування, зіставлення, порівняння, конкретизації, узагальнення, розвиток яких відбувається у процесі інтерпретування.

У якості методик дослідження було розроблено комплекс завдань на інтерпретацію, за допомогою яких можна виявити особливості інтерпретаційної діяльності особистості у молодшому шкільному віці. Вибірку дослідження склали учні молодших класів загальноосвітніх шкіл м. Дніпро, віком 9-10 років, 21 хлопчик та 24 дівчинки $(\mathrm{n}=45)$.

Об’єктом для інтерпретації у дослідженні було обрано тексти за такими критеріями: за характеристиками об'єкт інтерпретації має бути новим, неясним, неочікуваним, дивним, суперечливим, мінливим для суб'єкта інтерпретування, таким, що викликає труднощі в усвідомленні змістовно-смислових характеристик текстового матеріалу.

Дослідницький комплекс містить п’ять текстових завдань на інтерпретацію, різних за жанром та характеристиками, обов'язковим елементом яких $є$ наявність в них об’єктивних труднощів, що потребує певного інтерпретаційного зусилля. Запропоновані завдання складаються з умови, тексту, зміст якого характеризується певною складністю, та питань, що сприяють пошуку вирішення завдання на інтерпретацію. Вирішення завдання передбачає аналіз текстової ситуації: виявлення відомого і невідомого, очевидного й неочевидного.

В якості завдань на виведення абстрактного з конкретного у дослідженні були використані тексти притчі зі змістом, доступним розумінню дітей молодшого шкільного віку. Завдання на виявлення смислового протиріччя ставилася на матеріалі тексту з гумористичним змістом, специфічність якого полягає у наявності двох планів змісту на перетині двох контекстів, прямо не пов'язаних один з одним. У якості завдання на смислову аналогію були пропоновані прислів'я як вираз 3 двома смисловими планами, один 3 яких виражається в ньому безпосередньо, а інший виникає від застосування за подібністю у інших ситуаціях. В якості завдання на змістовну цілісність тексту було обрано незавершені історії з деякою смисловою невизначеністю, що потребує логічного іiі завершення на основі встановлення причинно-наслідкового зв'язку. Взаємовиключні за смислом ствердження склали завдання на визначення особистісного ставлення та обгрунтування думки.

\section{Результати \\ Results}

Кількісний аналіз вирішення молодшими школярами цих інтерпретаційних завдань показав, що здатність сприймати прямий смисл тексту виявлено у всіх дітей досліджуваної вибірки. Діти 9-10 років адекватно визначають прямі значення слів, 
словосполучень, речень, прямий смисл тексту в цілому. За параметром встановлення загальної авторської ідеї притчі, теми тексту, підтексту учні показали дещо нижчі результати (89\%). Менш вдало учні впоралися з завданням обгрунтувати власне судження щодо змісту притчі (78\%). В цілому, з вирішенням інтерпретаційних завдань на усвідомлення буквального та переносного смислу успішно впоралася переважна більшість молодших школярів (89\%).

Встановлення прямих значень слів та речень гумористичного тексту не викликає труднощів у більшості дітей (73\%). Але сприймання парадоксальності смислових планів тексту, виявлення неявного смислу, підтексту, суперечливості у поданій ситуації притаманне меншої кількості дітей (38\%). Це означає, що у дітей молодшого шкільного віку здатність до виявлення та декодування неявних смислів, що містяться у гумористичному тексті, які складають два плани тексту, не $\epsilon$ розвиненою достатньою мірою. 3 цими даними співвідносяться й дані за параметром тлумачення гумористичної ситуації: діти показали низькі результати у завданні зробити припущення, висунути гіпотезу щодо причин ситуації, яка склалася (29\%).

Показник за параметром визначення смислової аналогії вказує на таку тенденцію: майже у половини молодших школярів досліджуваної групи (47\%) не сформована здатність встановлювати семантичну подвійність тексту, відтворювати смислову аналогію. 3 цим параметром співвідноситься й показник параметра узагальнення, висновку щодо змісту прислів'я: лише частина дітей (47\%) спромоглася висловити власний умовивід щодо імпліцитного змісту прислів’я. Цей факт вказує на відсутність спроможності дитини встановити смислову аналогію двох планів метафори, унеможливлює розуміння ії переносного смислу та утруднює формування власного судження щодо змісту прислів’я.

Молодші школярі здатні адекватно встановлювати контекст ситуації, якщо вона не містить другого смислового плану. Адекватне розуміння ситуації було виявлено у переважної більшості дітей (98\%). Завдання на завершення історії також не викликало труднощів: майже всі діти (98\%) показали логічний причиннонаслідковий зв'язок наявного змісту ситуації та іï завершення. Дещо менше дітей спромоглися сформулювати причину поведінки персонажу історії (95\%). Не викликало труднощів й завдання висловити думку, як поводилася б дитина у подібній ситуації: молодші школярі здатні до формулювання власної позиції.

Аналіз отриманих даних показав, що молодші школярі здатні адекватно розуміти зміст протилежних за смислом стверджень та зіставити їх. Майже всі діти визначилися у своєму виборі, схилившись до одного з двох стверджень (98\%). Однак впевнене визначення власної позиції поєднується $з$ досить низьким показником за 
параметром обгрунтування цієї позиції (68\%). Формулювання власної точки зору на певне судження виявлено у більшості молодших школярів (91\%).

\section{Висновки Conclusion}

Результати дослідження особливостей інтерпретаційної діяльності молодших школярів дозволяють зробити певні висновки: (1) молодші школярі здатні виявляти та диференціювати буквальний і переносний смисл тексту; (2) сприймання підтексту, смислового протиріччя, що міститься у тексті, $є$ не розвиненим у них достатньою мірою; (3) встановлення семантичного зв'язку контекстів викликають труднощі; (4) здатність встановлювати семантичну подвійність тексту, відтворювати смислову аналогію у молодших школярів має недостатній рівень розвитку; (5) виявлена здатність адекватно встановлювати контекст ситуації, якщо вона не містить другого смислового плану; (6) здатність висловлювати власну точку зору, позицію, ставлення до певної текстової ситуації виражена середнім рівнем; (7) пояснення причин, обгрунтування точки зору молодшим школярам вдається меншою мірою.

\section{Література References}

Акімова, Н.В. (2012). Проблема розуміння тексту в сучасній психолінгвістиці. Наукові записки Національного університету «Острозька академія». Серія: Філологічна, 30, 104-106. http://nbuv.gov.ua/UJRN/Nznuoaf_2012_30_33

Барташников, А.А., Барташникова, И.А. (1998). Учись мыслить: Игры и тесты для детей 7 10 лет. Харьков: Фолио.

Валуйская, О.Р. (2012). Интерпретативность как потенциальное свойство текста. Вестник Волгоградского государственного университета. Сер. 2, Языкозниние, 2 (16), 210-

215. https://l.jvolsu.com/index.php/ru/component/attachments/download/586

Гижа, А.В. (2005). Интерпретация и смысл (Структура понимания гуманитарного текста). Харьков: Коллегиум.

Лингвистический энииклопедический словарь. (1990). Москва : Советская энциклопедия.

Славская, А.Н. (2002). Личность как субъект интерпретации. Дубна : Феникс+.

Тихомирова, Л.Ф. (2000). Формирование и развитие интеллектуальных способностей ребенка. Младшие школьники. Москва: Рольф.

Уланович, О.И. (2001). Текст и его понимание. Вестник МГЛУ. Серия 2. Психология, педагогіка. 3, 22-30. https://elib.bsu.by/handle/123456789/15104 
Шевченко, Н.Ф. (2013). Особистісний смисл у структурі смислоутворювальної активності особистості. Матеріали I Міжнародної науково-практичної конференції «Когнітивні та емоиійно-поведінкові фактори повноцінного функиіонування людини: культурноісторичний підхід». (рр. 33-35). Харків: ХНПУ. http://hnpu.edu.ua/sites/default/files/files/Kaf_psihologii/konf_2013.pdf

Ядровская, Е.Р. (2012). Развитие интерпретационной деятельности читателя-икольника в проиессе литературного образования. Санкт Петербург : ООО «Книжный дом». 